\title{
メソ気象モデルと台風ボーガスを用いた伊勢湾台風時の 風の場のシミュレーション
}

\section{1.はじめに}

台風に伴う高潮・高波計算において，その入力とな る風の与え方には, いわゆる「台風モデル」(水平 2 次元 の意味を含めて, 以降「2D台風モデル」と記述）に基づ いて与える方法と, 国際的な気象機関から全球・領域気 象モデルの出力として提供される客観解析值を用いる方 法の 2 つがある.しかしながら, 前者には地形の影響を十 分に考慮することができないという大きな問題があり, この問題解決のためにこれまで様々な手法が提案されて いるものの（例えば，小泉・鳥山，1996），信頼性や物理 的根拠, 適応範囲等の面で全てを満足する手法は現在ま でのところ見当たらない.また後者には低い時間・空間 分解能に起因して, 観測風との位相のずれや風速の過小 評価等の問題点が指摘されている（例えば, 山下他, 1996).

そこで本研究では, $2 \mathrm{D}$ 台風モデルの 3 次元拡張版とも 言うべき台風ボーガス (bogus) を用いて高解像度の解析 場を作成し，この場を入力としてメソ気象モデルを走ら せることにより，地形の影響を含んだ風の場の計算を 行った. 計算対象は 1959 年 9 月の伊勢湾台風とし, 全球 客観解析值には NCEP（米国環境予測センター）の 2.5 度格子データを用いた。 またメソ気象モデルには, ペン シルバニア州立大と NCAR (米国大気研究センター) で 共同開発された MM $5\left(5^{\text {ht }}\right.$-generation Mesoscale Model）を用いた。

\section{2. 計算手 法}

\section{（1）メソ気象モデル MM5}

このモデルは雲物理過程, 放射過程, 境界層過程, 地 表面過程を含んだ非静力学モデルである。計算領域には 多重ネスティングが可能になっており,本計算では, 図一 1 に示すように, $27 \mathrm{~km}$ 格子，9 $\mathrm{km}$ 格子， $3 \mathrm{~km}$ 格子の 3 領域を設定した.鉛直方向の気圧準拠座標に関しては,

\footnotetext{
* 正会員 博(理) 岐阜大学助手 大学院工学研究科環境エネルギー システム専攻

** 愛知県名古屋市役所

****正会員 工 博 岐阜大学教授 大学院工学研究科環境エネルギー システム専攻
}

$100 \mathrm{hPa}$ 高度面 (約 $16 \mathrm{~km}$ ) で $\sigma=0$ となるように設定し, $\sigma=0.998$ の風を高度 $10 \mathrm{~m}$ の地表風として出力した.

（2）台風ボーガス

台風半径 $(1000 \mathrm{~km})$ 内の地上気圧は, Schloemer の式

$$
P=P_{c}+\Delta P \exp \left(-\frac{r_{0}}{r}\right)
$$

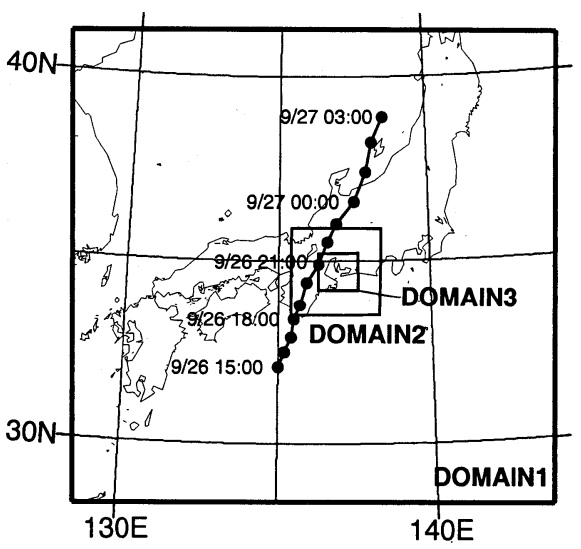

図-1台風経路と計算領域

表一1 計算に用いた台風パラメータ

\begin{tabular}{r|c|c|c|c|c|c}
\hline 月日 & $\begin{array}{c}\text { 時刻 } \\
(\mathrm{JST})\end{array}$ & $\begin{array}{c}\text { 経度 } \\
(\mathrm{deg})\end{array}$ & $\begin{array}{c}\text { 緯度 } \\
(\mathrm{deg})\end{array}$ & $\begin{array}{c}\text { 中心気圧 } \\
(\mathrm{hPa})\end{array}$ & $\begin{array}{c}\text { 最大風速 } \\
\text { 径 }(\mathrm{km})\end{array}$ & $\begin{array}{c}\text { 周辺気 } \\
(\mathrm{hPa})\end{array}$ \\
\hline 9 月 26 日 & $15: 00$ & 135.0 & 32.1 & 925 & 109 & 1015 \\
\hline 26 日 & $16: 00$ & 135.2 & 32.5 & 925 & 105 & 1014 \\
\hline 26 日 & $17: 00$ & 135.4 & 32.9 & 925 & 103 & 1014 \\
\hline 26 日 & $18: 00$ & 135.5 & 33.4 & 929 & 101 & 1013 \\
\hline 26 日 & $19: 00$ & 135.7 & 33.8 & 935 & 104 & 1012 \\
\hline 26 日 & $20: 00$ & 135.9 & 34.4 & 940 & 104 & 1012 \\
\hline 26 日 & $21: 00$ & 136.3 & 34.9 & 945 & 85 & 1011 \\
\hline 26 日 & $22: 00$ & 136.6 & 35.5 & 950 & 97 & 1010 \\
\hline 26 日 & $23: 00$ & 136.9 & 36.0 & 960 & 124 & 1009 \\
\hline 9 月 27 日 & $0: 00$ & 137.5 & 36.6 & 968 & 148 & 1008 \\
\hline 27 日 & $1: 00$ & 137.9 & 37.4 & 970 & 163 & 1007 \\
\hline 27 日 & $2: 00$ & 138.1 & 38.2 & 970 & 153 & 1006 \\
\hline 27 日 & $3: 00$ & 138.5 & 38.9 & 966 & 117 & 1005 \\
\hline
\end{tabular}



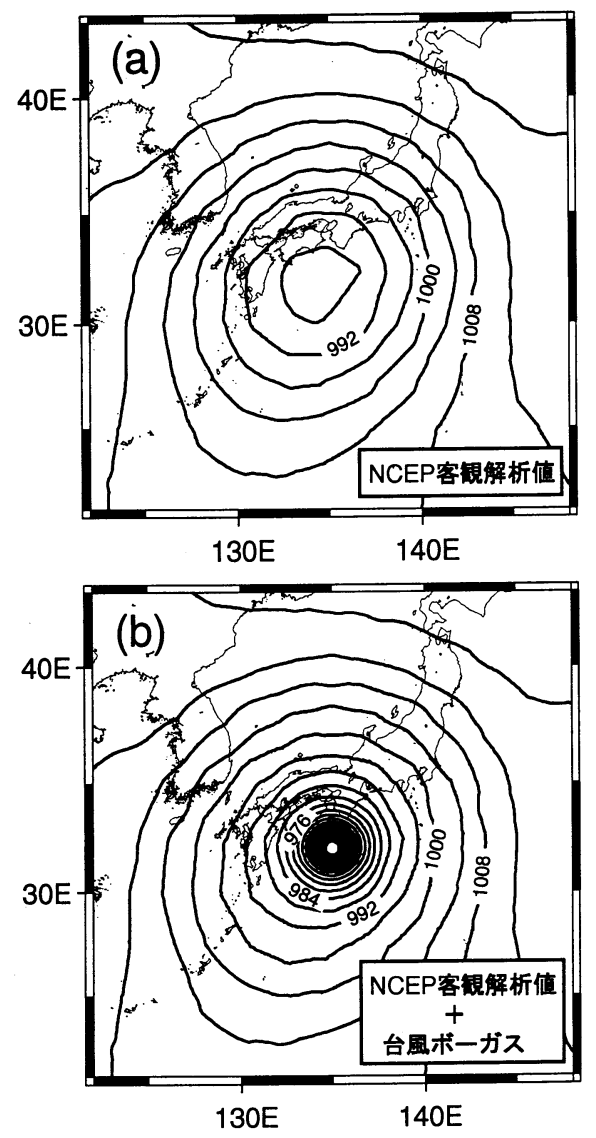

図一2 1959 年 9 月 26 日 15 時の地上気圧 $(\mathrm{hPa})$

を伊勢湾台風時の名古屋, 津, 伊良湖の気圧観測值に最 適フィットさせることにより求めた。ここで， $P_{c}$ は中心 気圧, $\Delta P\left(=P_{\infty}-P_{c}\right)$ は周辺気圧 $P_{\infty}$ と中心気圧 $P_{c}$ との 差, $r_{0}$ は最大風速半径である。計算に用いた台風パラ メー夕を表一1に示す.

台風ボーガスには，現在気象庁の現業で使われている ANL ボーガス（上野，2000）の手法を用いた。この台風 ボーガスは, 高度 $D$ 值（台風半径内の等圧面高度 $Z$ の周 辺值からの偏差) の 3 次元軸対称構造を, 複数の台風の コンポジット解析から求められた解析関数を用いて記述 するものである，任意の気圧面上の半径 $r$ の $D$ 值は,

$$
D=\Delta Z(r, p)+\frac{R}{g} \int_{p_{B}}^{P_{s}} T_{B} d(\ln p)
$$

と書ける.ここでは気体定数, $g$ は重力加速度であり, $P_{B}$ 及び $T_{B}$ はそれぞれ地上気圧 $P_{s}$ と温度 $T$ の台風周辺值 である. $\Delta Z$ は次のように関数表示される。

$$
\begin{aligned}
\Delta Z(r, p)= & \beta\left(\ln p-\ln p_{s}\right) \times\left\{\left[\ln p-\ln \left(P_{\mathrm{Ta} 0}\right)\right]^{2}+\zeta\right\}^{-n} \\
& \times \exp \left\{\delta\left[\ln p-\ln \left(P_{\mathrm{Ta}} x\right)\right]^{2}\right\} \cdots \cdots \cdots(3)
\end{aligned}
$$

ここで, $P_{\mathrm{Ta}}$ は温度偏差が最大になる気圧レベル, $P_{\mathrm{Ta} 0}$ は温度偏差が 0 となる気圧レベルに対応する。

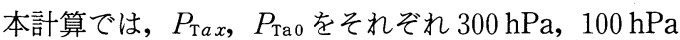
として計算した。 $\delta$ とは $p_{s}, P_{\mathrm{Ta} x}, P_{\mathrm{Ta} 0}$ の関数であり, $\beta$ は台風中心に扔いて $p=P_{\text {Ta } x}$ で $D=0$ という仮定に基 づいて計算した。等圧面高度場の非対称成分は, NCEP 客観解析值を用いて, 等圧面毎に方位角平均高度を台風 中心からの距離の関数として求めることにより算出し た。非対称成分を含めた風の場は，軸対称ボーガスの高 度場及び方位角平均高度場についての傾度風平衡の関係 から算出した。 温度場は, 高度場について静力学平衡を 仮定することにより求めた。

こうして得られた台風ボーガスを, 半径と共に減少し て台風半径の所で 0 となるような荷重関数により客観解 析值に組み込み, 最終的に水平 0.1 度格子,鉛直 17 層(地 表〜 $100 \mathrm{hPa}$ 面)の初期場を作成した. 図一2(a) は NCEP 客観解析值による 1959 年 9 月 26 日 15 時の地上気圧分 布であり, 中心気圧は $988 \mathrm{hPa}$ 程度である.これに対して 上記の手法により台風ボーガスを組み込んだ図一2(b) では, 中心気圧が $925 \mathrm{hPa}$ までシャープに下降している. 同様な台風ボーガスを計算時間内（9 月 26 日 15 時〜 9 月 27 日 3 時)の 1 時間毎に作成した。そして台風の進路 が実測進路からずれないように，1 時間毎に 4 次元デー 夕同化を行った。ただし，地形の影響をより良く再現す るために風速場についてはデー夕同化を行っていない.

\section{（3） 2D 台風モデル}

気圧分布には先に述べた Schloemer の式（1）を用い, 傾度風から地表風への変換には Mitsuta and Fujii （1986）の手法を用いた。この手法では, 傾度風に対する 地表風の比は台風中心からの半径の関数として,

$$
\begin{aligned}
G(x)= & G(\infty)+\left[G\left(x_{p}\right)-G(\infty)\right] \\
& \times\left(\frac{x}{x_{p}}\right)^{k-1} \exp \left\{\left[1-\frac{1}{k}\right]\left[1-\left(\frac{x}{x_{p}}\right)^{k}\right]\right\}
\end{aligned}
$$

と定義される.ここで $x$ は最大風速半径で無次元化され た距離 $\left(r / r_{0}\right)$ であり, $k$ は形状パラメー夕, $x_{p}$ は $G(x)$ が 最大となるの值, は台風周辺での風速比(海上值 $2 / 3$ ) で ある. 地表風の吹き込み角は $30^{\circ}$ とした。

\section{3. 計算結果}

図一3にMM 5 によって計算された 26 日 20〜22 時の 地表風ベクトルを示す. 20 時に台風中心は伊勢湾から見 て西南西の方向にあり, 伊勢湾湾口では南東の風, 湾内 では東風となっている. 計算開始時刻の 15 時から 20 時 までは概ねこのような東〜南東風の場が続いている. 21 時には, 台風接近に伴って湾内全体で南風が強まり, 台 風進行方向右前方にあたる湾奥部では台風中心に吹き込 む強い南東風が見られる.中心が北に抜けた 22 時には, 湾内全域で南西風の場となった。 その後計算終了時刻の 


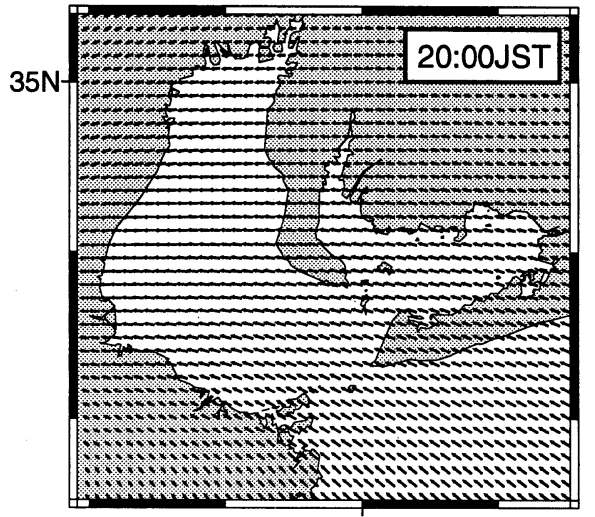

137E
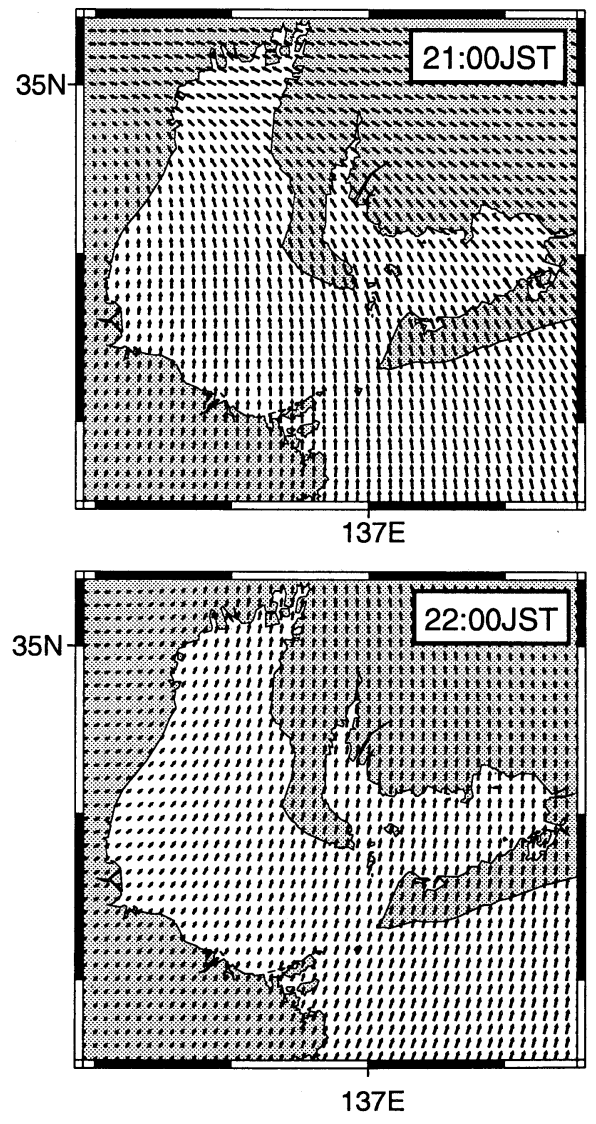

図一3 MM5 による地表風べクトル計算值

27 日 3 時までほぼこのような南西〜西風の場が続いて いる.

図一 4 は計算時間内の風速分布を連続的に示したもの である.全体的な場のパターンは 20 時までほとんど変化 していない.この時間帯の際立った特徵は, 強風域が湾 外から湾内南西部に入り込んでいることである。陸面に 比べて海面は粗度が小さいために，東寄りの風は湾口部
から湾内へと侵入しやすいものと解釈できる。また標高 数百 $\mathrm{m}$ の山地を有する志摩半島への上陸を避けて風が 半島を迁回する効果もこの強風域形成の一因であろうと 考えられる. 台風通過後には, 等風速線が南北に走り, 風は湾の西側で弱く東側で強くなる傾向が見られる。こ の時間带の風向は南西〜西であることから，風上側に位 置する志摩半島や紀伊山地，鈴鹿山脈等の風の遮蔽効果 がこの伊勢湾西岸沿いの風を弱めているものと解釈でき る.

地形の影響が随所に見られる図一 4 に対して，2D台風 モデルによる計算結果を示した図一 5 には，当然ながら そのような地形の影響は見られない. $2 \mathrm{D}$ 台風モデルによ る風の場は, 台風自体の構造にのみ依存する。その典型 例が, 26 日 21 時に伊勢湾上に見られる風速 $40 \mathrm{~m} / \mathrm{s}$ 以上 の強風域である. 同じ気圧分布に基づいた台風ボーガス を 4 次元同化しているにも関わらず，同時刻の MM 5 計 算值（図一4）にはこの強風域に相当する分布は見出せな い. MM 5 計算值では, 台風との位置関係に関わらず, 湾 外での風速は伊勢湾内の風速を常に上回っており，地形 の影響による内湾での風の弱まりを如実に示す結果と なっている.

\section{4. 考察}

図一6 及び図一7 は名古屋と伊良湖において MM 5 計 算值, 2D 台風モデル計算值を観測值と比較したものであ る. 図一6 の風向は, 0 度が北, 90 度が東, 180 度が南, 270 度が西を示している. 台風通過後の比較では, $2 \mathrm{D}$ 台 風モデルに対してMM 5 の計算值に若干の改善が見ら れるが，台風接近前には明確な改善は見られない。これ

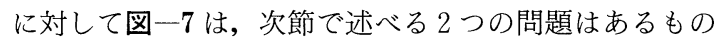
の，MM 5 を用いることで風速が大きく改善され得るこ とを示している. 名古屋での $2 \mathrm{D}$ 台風モデル計算值は, 台 風接近前では過大評価, 通過直前から過小評価という明 確な傾向を示すが，この点について MM 5 計算値は随分 と改善されている. 藤井他（1998）は, 台風時の観測値 に基づき,名古屋では東風に比べて西風の方が地表風/傾 度風比が大きくなることを示しているが，上記の結果は MM 5 を用いることによりこうした地形の影響が考慮可 能なことを示している.

伊良湖については別な観点から改善が見られる。伊良 湖は比較的海の近くに位置するため, $2 \mathrm{D}$ 台風モデルの計 算で用いられる陸上用パラ,メータ $G(\infty)=1 / 2$ では風速 が極端に過小評価されてしまっている.ここでは示さな いが,これを海上用のパラメータ $G(\infty)=2 / 3$ に変更する と観測值とほほ同様な值が得られる。すなおち，伊良湖 と名古屋は同じ陸上であっても周辺地形の影響によっ て,地表風/傾度風比は全く異なる.MM 5 を用いる最大 

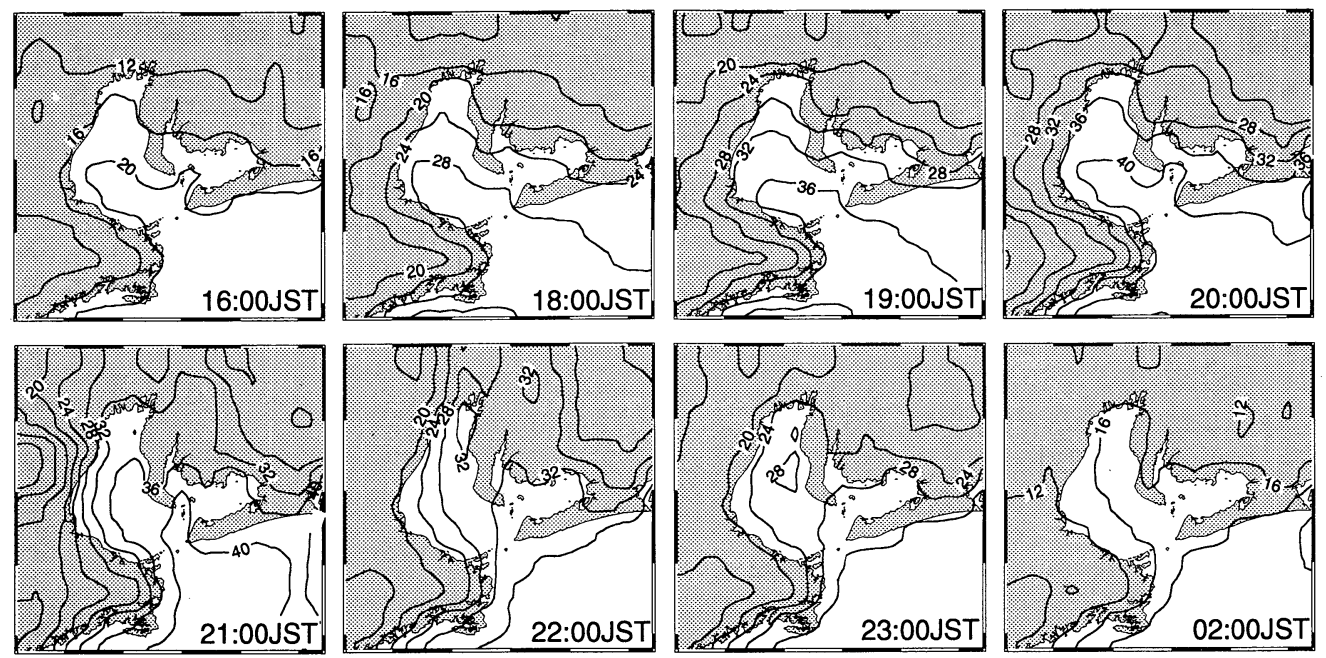

図一4 MM5 による地表風速分布 $(\mathrm{m} / \mathrm{s})$
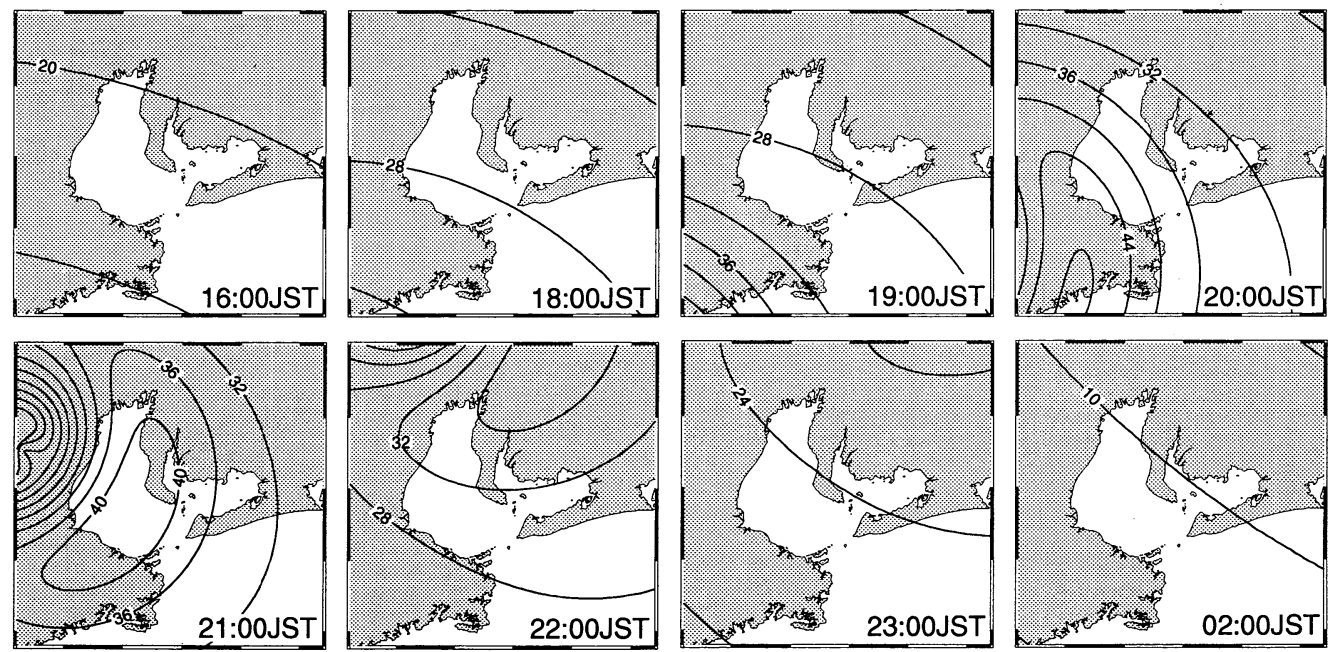

図一5 2D 台風モデルによる地表風速分布 $(\mathrm{m} / \mathrm{s})$

のメリットは, 地表風/傾度風比や吹き込み角が大気力学 に基づき，時間及び空間の関数として格子毎に計算でき るという点である．図一7 の名古屋と伊良湖での MM 5 訃算值の大きな差は，まさにこうした地形の影響を反映 して算出されたものであり，一義的にしかパラメー夕を 決められない $2 \mathrm{D}$ 台風モデルとの決定的な違いとなって いる.

しかしながら，図一7 は台風ボーガスに関する 2 つの 大きな問題を示唆している.1つは名古屋で見られる最 大風速の過小評価である.この要因として Schloemerの 式（1）の問題が考えられる. Schloemer の式は中心付 近で気圧勾配が小さく鍋底型になるという特徵を持つ (岡田，2000)。この特徵は図一2（b）においても確認で
き, これが台風最接近時に名古屋の最大風速を過小評価 しているものと考えられる。従って今後は他の気圧分布 式を用いた台風ボーガスの作成も検討していく必要があ る.もう $1 つ の$ 問題は，伊良湖において顕著に見られる ように, 台風通過後の風速が過大評価になっている点で ある．この原因として台風通過後の台風パラメー夕の問 題が考えられる. 本研究では計算対象を伊勢湾としてい ることから，台風中心と伊勢湾中央部を結ぶ直線上での 一次元的な気圧分布を想定した上で，伊勢湾周辺の気圧 観測值から台風パラメー夕を算出した。対象領域の観測 值だけを使うことにより，その領域での気圧場の再現性 は向上する一方で, 台風通過後には最大風速半径が 150 $\mathrm{km}$ を超えて算出される等, 2 次元的な台風の構造とし 

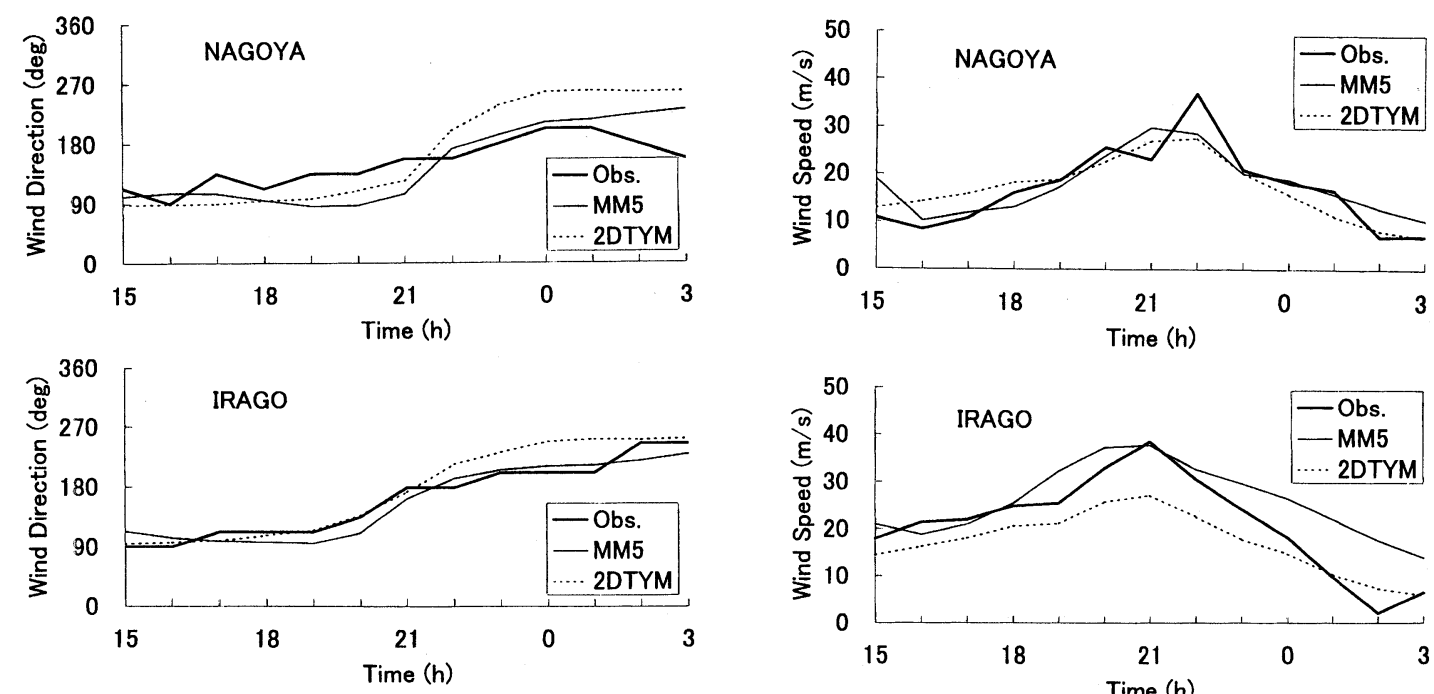

図-6 名古屋と伊良湖での風向に関する観測值と計算值の 比較

ては非現実的な值となるという問題が生じる.以上 $2 つ$ の問題に共通して, モデルの入力值であり, 台風ボーガ スの基礎でもある地上気圧分布の改善が今後の計算精度 向上の鍵を握っていると言える。

\section{5. まと め}

メソ気象モデルと台風ボーガスを組み合わせることに より, 半島間の湾口に扔ける風速強化, 山岳や半島によ る風の遮蔽効果, 湾外と湾内での風速コントラスト等, 従来の 2D 台風モデルでは表現できなかった地形の影響 を受けた風の場の特性を再現可能なことが明らかになっ た.ただし，モデル入力值となる台風ボーガスの作成に 関してはまだまだ改善の余地が多くあり，特に基礎とな る地上気圧分布の改善が今後の中心検討課題である.

謝辞：本研究で用いた伊勢湾台風時の地上気象観測 データは国土交通省中部地方整備局より提供して頂い た.また地球フロンティア研究システムの王自発氏と京 都大学防災研究所の吉野純氏には MM 5 の使用上の諸

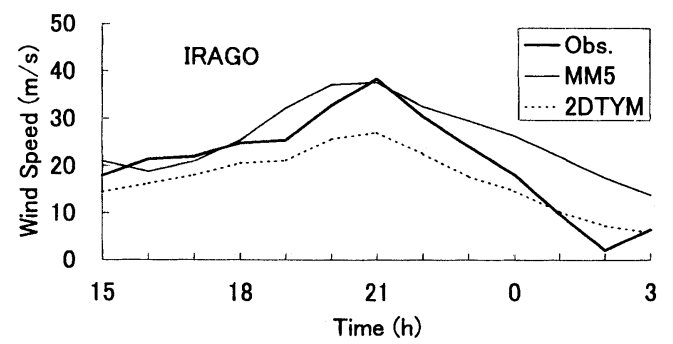

図一7 名古屋と伊良湖での風速に関する観測值と計算値の 比較

問題に関して的確な助言を頂いた。さらに，本研究は日 本学術振興会科学研究費基盤 (B) (2) 13555141 にる成 果であり，ここに併せて謝意を表する。

\section{参 考 文 献}

上野 充 (2000): 数值モデルによる台風予報, 気象研究ノート (第 3 章)，第 197 号，pp. 131-286.

岡田弘三 (2000): 高潮を起こす気象の場とそのモデル化, 月刊 海洋, 第 365 号, pp. 735-742.

小泉俊雄・鳥山智樹 (1996)：地形解析をもとに台風時の地表の 風向, 風速を算定する実験式作成に関する理論的研究, 千葉 工業大学研究報告, 理工編, 第 43 号, pp. 105-116.

檜垣将和・小西達男 (2000)：高潮予測技術, 月刊海洋, 第 365 号, pp. 771-776.

藤井 健・光田 寧・植田洋匡 (1998)：台風時における気圧場 から計算した風速と実測された風速との関係(第 2 報), 京都 大学防災研究所年報, 第 41 号, pp. 399-410.

山下隆男・路 明・榊原 弘 (2000): 砕波による海面せん断応 力を導入した吹送流の数值解析モデル, 海岸工学論文集, 第 47 巻, pp. 121-125.

Mitsuta Y. and T. Fujii (1986): Synthesis of typhoon wind patterns by numerical simulation, Natural Disaster Sci ence, Vol. 8, pp. 49-61. 